\title{
4-Dihydromethyltrisporate dehydrogenase from Mucor mucedo, an enzyme of the sexual hormone pathway: purification, and cloning of the corresponding gene
}

\author{
Katrin Czempinski, ${ }^{2}$ Volker Kruft, ${ }^{3}$ Johannes Wöstemeyer ${ }^{1}$ \\ and Anke Burmester ${ }^{1}$ \\ Author for correspondence: Anke Burmester. Tel: +493641 630331. Fax: + 493641630321.
e-mail: b5buan@ pop3.uni-jena.de
}

${ }^{1}$ Lehrstuhl fur Allgemeine Mikrobiologie und

Mikrobengenetik, FSU

Jena, Neugasse 24, 07743

Jena, Germany

2 Institut für Genbiologische Forschung, Ihnestraße 63 , 14195 Berlin, Germany

3 Applied Biosystems $\mathrm{GmbH}$, Brunnenweg 13,64321 Weiterstadt, Germany

\begin{abstract}
We have purified the NADP-dependent 4-dihydromethyltrisporate dehydrogenase from the zygomycete Mucor mucedo. The enzyme is involved in the biosynthesis of trisporic acid, the sexual hormone of zygomycetes, which induces the first steps of zygophore development. Protein was obtained from the (-) mating type of $M$. mucedo after induction with trisporic acid, and purified by gel filtration and affinity chromatography steps. On SDS-PAGE a band with an apparent molecular mass of $33 \mathrm{kDa}$ was ascribed to the enzyme. After transferring onto PVDF membranes the protein was digested with endoprotease Lys- $C$, and several peptides were sequenced. Oligonucleotides derived from protein sequence data were used for PCR amplification of genomic $M$. mucedo DNA. The PCR fragment was used as probe for isolation of the corresponding CDNA and complete genomic DNA clones. Comparison of protein and DNA sequence data showed that the cloned fragment corresponded to the purified protein. Search for similarity with protein sequences of the Swiss-Prot database revealed a relationship to enzymes belonging to the aldo/keto reductase superfamily. Southern-blot analysis of genomic DNA with the labelled cloned fragment detected a single-copy gene in both mating types of $M$. mucedo. PCR with genomic DNA from other zygomycetes gave rise to several fragments. Hybridization analysis with the cloned $M$. mucedo fragment showed that a fragment of similar length crosshybridized in Blakeslea trispora (Choanephoraceae) as well as in Parasitella parasitica and Absidia glauca (Mucoraceae). The promoter region of the gene contains DNA elements with similarity to a cAMP-regulated gene of Dictyostelium discoideum.
\end{abstract}

Keywords: mating type, trisporic acid, oxidoreductase, Mucor mucedo, aldo/keto reductase superfamily

\section{INTRODUCTION}

Early studies of sexual reactions between different species of zygomycetes often revealed the development of structures which tesembled stages of sexual differentiation, but which could not develop to fertile zygospores (Burgeff, 1924; Blakeslee \& Cartledge, 1927). These experiments

Abbreviations: RT, reverse transcriptase; TA, trisporic acid.

The EMBL accession number for the sequence reported in this paper is 273640 . were used to classify $(+)$ and $(-)$ mating types of zygomycetous strains. Later, the sexual pheromone pathway of Mucor mucedo and Blakeslea trispora was described in detail (Nieuwenhuis \& van den Ende, 1975; Bu'Lock et al., 1976; see Gooday, 1994, for a review). The two mating types produce different precursors which can be converted exclusively by the complementary mating type to the active form, the sexual hormone trisporic acid (TA). The (+)-type-specific precursor 4-dihydromethylTA is converted to methyl-TA by a dehydrogenase of the (-) mating type and subsequently to TA by a (-)-typespecific esterase. TA stimulates its own production and 
also the activity of the dehydrogenase (Werkman, 1976). NADP and to some degree also FAD are accepted as cofactors. Enzyme activity could be found in cell extracts of both mating types of $M$. mucedo. However, no conversion of 4-dihydromethyl-TA to TA could be found in vivo with the $(+)$ mating type (Werkman, 1976).

We are interested in the mycoparasitic interaction between Parasitella parasitica and its host Absidia glauca, both belonging to the family Mucoraceae. Some physiological observations in this system led to the hypothesis that links exist between the sexual development and the parasitic interaction. One argument for this assumption is the fact that the parasite discriminates between the mating types of the host. Analogous to the mating-type reaction, only (+)-type $P$. parasitica strains infect $(-)$-type $A$. glauca strains, and only (-)-type $P$. parasitica strains infect (+)type $A$. glauca strains (Burgeff, 1924). Some similarities between sexual and parasitic development could be found. In the sexual reaction cytoplasmic fusion occurs between special regions of hyphal tips, the progametangia, of the two mating types. The interaction between parasite and host also involves cytoplasmic fusion between the partners. Recently, we demonstrated an active parasexual gene transfer system from the parasite to the host (Kellner et al., 1993). P. parasitica infects a wide variety of other fungal species, all belonging to the order Mucorales. The sexual communication system works between different species of this order. It was demonstrated that TA isolated from B. trispora induces zygophores in $M$. mucedo (Werkman \& van den Ende, 1973). We also showed by thin-layer chromatography that complementary combinations of $P$. parasitica and $A$. glauca were able to synthesize TA cooperatively. One idea is that the sexual pheromone system in this parasitic interaction also plays a role in host recognition. Thus, we ate interested in isolating genes involved in sexual differentiation. In another approach we characterized cDNA clones of $P$. parasitica, the expression patterns of which are regulated by trisporic acid. Some clones could be identified, most of them belonging to multigene families (Vetter et al., 1994).

In this paper we describe the identification and isolation of the gene for 4-dihydromethyl-TA dehydrogenase of $M$. mucedo.

\section{METHODS}

Strains and growth conditions. The following strains were used: $M$. mucedo CBS 109.16(-) and CBS 144.24(+); B. trispora CBS 131.59(-), CBS 130.59(+) and ATCC 14060(-); $A$. glauca CBS 101.48(+) and CBS 100.48(-); P. parasitica CBS 208.28(-), CBS 207.28(+), ATCC 11077(-) and CBS 412.66(+); and $P$. blakesleeanus strains of $(-)$ and $(+)$ mating type. The $M$. mucedo strains and B. trispora CBS 131.59 and CBS 130.59 were a gift from $\mathrm{H}$. van den Ende (University of Amsterdam). The $P$. blakesleeanus strains were from the Pilzkulturensammlung Weimar, Jena. The other strains were from the Centraalbureau voor Schimmelcultures, Baarn, The Netherlands, or the American Type Culture Collection. For enzyme preparations $M$. mucedo strain CBS 109.16(-) was grown for 3-4 d in liquid culture of complete medium (Wöstemeyer, 1985) with $10 \mathrm{~g}$ maltose $1^{-1}$ as carbon source. At $12 \mathrm{~h}$ before harvesting, mycelia were induced with $\mathrm{TA}$ at a final concentration of $10 \mu \mathrm{g} \mathrm{ml}^{-1}$. Zygophore induction by $\mathrm{TA}$ and 4-dihydromethyi-TA was tested according to van den Ende \& Stegwee (1971). For this purpose $M$. mucedo was grown for approximately $4 \mathrm{~d}$ on Petri dishes containing the following medium: $2 \%(\mathrm{w} / \mathrm{v})$ maltose, $0 \cdot 1 \%(\mathrm{w} / \mathrm{v})$ yeast extract, $100 \mathrm{mM} \mathrm{KNO}, 37 \mathrm{mM} \mathrm{KH}_{2} \mathrm{PO}_{4}, \quad 10 \mathrm{mM} \mathrm{MgSO}, 7 \mathrm{H}_{2} \mathrm{O}$, $1.5 \%$ agar (Oxoid). After induction with appropriate substances for $12 \mathrm{~h}$, the zygophores were counted under the stereomicroscope.

Purification and sequencing of 4-dihydromethyl-TA dehydrogenase. Enzyme was isolated from mycelia of (-)-type $M$. mucedo. Mycelia were washed once with $\mathrm{H}_{2} \mathrm{O}$ in a Büchner funnel, pulverized under liquid nitrogen and resuspended in $50 \mathrm{mM}$ Tris $/ \mathrm{HCl} \mathrm{pH} 8$ on ice. After centrifugation at $41000 \mathrm{~g}$ and $4{ }^{\circ} \mathrm{C}$ for $50 \mathrm{~min}$ the supernatant was concentrated by ultrafiltration on membranes with a cut-off size for proteins of $30 \mathrm{kDa}$ (YM30, Amicon). Protein amounts were determined (Stoschek, 1990) and the retentate containing the enzyme activity was purified by gel filtration on a Sephadex G 200 column (volume $200 \mathrm{ml}$, flow rate $0 \cdot 02-0.05 \mathrm{ml} \mathrm{min}^{-1}$ ). The column was equilibrated with $50 \mathrm{mM}$ Tris/ $\mathrm{HCl} \mathrm{pH} 8,1 \mathrm{mM}$ EDTA. Fractions containing enzyme activity were pooled and concentrated by ultrafiltration on Centriprep-30 (Amicon). The retentate was separated by affinity chromatography on a Blue Sepharose CL-6B (Pharmacia) column (volume $10 \mathrm{ml}$, flow rate $0.2-0.5 \mathrm{ml} \mathrm{min}^{-1}$ ) equilibrated with $50 \mathrm{mM}$ Tris $/ \mathrm{HCl} \mathrm{pH} 8$, $1 \mathrm{mM}$ EDTA. After washing the column with the same buffer, proteins wete eluted with $10 \mathrm{mM} \mathrm{NADP}$ in $50 \mathrm{mM}$ Tris/ $\mathrm{HCl}$ pH 8, 1 mM EDTA. Proteins were concentrated and desalted by washing in Centricon-10 (Amicon) ultrafiltration tubes to remove NADP ions. Fractions containing enzyme activity were separated by SDS-PAGE according to Laemmli (1970). After electrophoresis, proteins were transferred onto PVDF membranes (Immobiton, Millipore). After staining with $0.5 \%$ Ponceau $\mathrm{S}$ (Sigma) in $1 \%(\mathrm{v} / \mathrm{v})$ acetic acid, the appropriate protein band was cut out, fragmented with endoprotease Lys-C, separated by HPLC on a Vydac C18-column, and sequenced as described by Braun et al. (1994).

Enzyme assay and isolation of TA and 4-dihydromethyl-TA. TA was isolated as described by van den Ende (1968) from mixed cultures of both mating types of $B$. trispora. 'TA was extracted from acidificd culture medium with chloroform containing $5 \%(\mathrm{v} / \mathrm{v})$ 2-propanol. 4-Dihydromethyl-TA was obtained by methylation and reduction of isolated TA suspensions (Werkman, 1976). Bioactivity of TA and 4dihydromethyl-TA was measured by zygophore induction and the compounds were analysed by thin-layer chromatography on silica gel $60 \mathrm{~F}_{254}$ (Merck) according to Werkman \& van den Ende (1973). Dehydrogenase activity was measured as previously described (Werkman, 1976). Appropriate protein amounts were incubated for $1 \mathrm{~h}$ at $35^{\circ} \mathrm{C}$ in the dark in a total volume of $0.5 \mathrm{ml}$ with $200 \mu \mathrm{g}$ 4-dihydromethyl-TA, $100 \mathrm{mM}$ Tris/ $\mathrm{HCl} \mathrm{pH} 7.8,0.24 \mathrm{mM}$ nitro blue tetrazolium (Sigma), $0.13 \mathrm{mM}$ phenazine methosulfate, $0.78 \mathrm{mM}$ NADP, $0.2 \%$ gelatin. The reaction was stopped by acidifying the solution to pH 1 with $\mathrm{HCl}$. The difference in absorbance was measured at $540 \mathrm{~nm}$. The standard curve was established by reducing nitro blue tetrazolium non-enzymically to formazan with $\mathrm{N} A \mathrm{DPH}$ according to Nachlas et al. (1960). One unit of 4-dihydromethylTA dehydrogenase activity is defined as the amount of enzyme forming $1 \mu \mathrm{g}$ formazan under the conditions described above.

PCR conditions, sequencing and hybridizing conditions. PCR conditions were similar to those described previously (Burmester \& Czempinski, 1994). The PCR reaction contained, in a volume of $20 \mu \mathrm{l}: 25 \mathrm{ng}$ genomic DN $A, 10 \mathrm{pmol}$ of each primer, $0.2 \mathrm{mM}$ dNTPs, $3 \mathrm{mM} \mathrm{MgCl}, 10 \mathrm{mM}$ Tris $/ \mathrm{HCl}$ 
pH 8.3, $50 \mathrm{mM} \mathrm{KCl}, 0.01 \%$ gclatin and $2 \mathrm{~L}$ Taq polymerase (Boehringer). Fragments were amplified in a programmable water bath (Grant AG005 Autogene IT, CLF analytische Laborgeräte) for 30 cycles with the following temperature profile: $0.3 \mathrm{~min}$ at $94^{\circ} \mathrm{C}, 0.3 \mathrm{~min}$ at $45^{\circ} \mathrm{C}, 1 \mathrm{~min}$ at $72^{\circ} \mathrm{C}$. The following primers were chosen: P1, 5'-CGAATTCIC G/T G/A TCIA A/G IGCCCA-3'; and P2, 5'-CCAGCTGGAA T/C ACIT'T C/T CA-3' (I: dIMP).

To facilitate the cloning procedure, the primers contained restriction sites for EroRI or PmiI, respectively (shown underlined). PCR fragments were restricted with both enzymes and ligated into the EcoRI and Smal restriction sites of the polylinker region of pBluescript $\mathrm{KS}^{+}$, pBluescript $\mathrm{SK}^{-}$ (Stratagene) or pTZ18R (Pharmacia Biotech). Ligation products were transformed by standard procedures into Escherichia coli XL1 Blue (Bullock et al., 1987). Stringent hybridization conditions for Southern blots (Southern, 1975) were as described previously (Burmester \& Czempinski, 1994). A partial gene library was constructed of $M$. mucedo (-)-type genomic DNA. Genomic DNAs of M. mucedo strain CBS 109.16 were prepared according to the method described previously (Burmester \& Wöstemeyer, 1986). DNAs were restricted with $S_{a c} \mathrm{I}$ and $\mathrm{BamHI}$, separated on $0.8 \%$ agarose gels and fragments $4-5 \mathrm{~kb}$ in size werc eluted from the gels. Fragments were ligated into the Bam HI and SacI site of the polylinker region of $\mathrm{PT} Z 18 \mathrm{R}$ and transformed into E. coli XL1 Blue. Approximately $10^{4}$ transformants were picked on Petri dishes and used for colony filter hybridization with the radioactively labelled PCR fragment as probe. A genomic clone was isolated, containing a $4.5 \mathrm{~kb}$ $\mathrm{Sac} \mathrm{I} / \mathrm{BamHI}$ fragment with the whole gene. RNA was prepared from (-)-type $M$. mucedo liquid cultures which were induced with TA $4 \mathrm{~h}$ before treatment. Liquid cultures of mycelium were harvested by filtration and homogenized in a mortar under liquid nitrogen. After evaporation of liquid nitrogen, the resulting powder was suspended in $8 \mathrm{M}$ guanidine/HCl, $20 \mathrm{mM}$ MES $/ \mathrm{KOH}$ pH $7.0,20 \mathrm{mM}$ EDTA, $1 \%(\mathrm{v} / \mathrm{v}) \beta$-mercaptoethanol. After centrifugation at $5000 \mathrm{~g}$ for $5 \mathrm{~min}$ the supernatant was extracted with 1 vol. phenol/chloroform/isoamyl alcohol $(25: 24: 1$, by vol.). The aqueous phase was mixed with 0.05 vol. $1 \mathrm{M}$ acetic acid and $0.7 \mathrm{vol} .99 \%$ ethanol and precipitated overnight at $-20^{\circ} \mathrm{C}$. After centrifugation at $5000 \mathrm{~g}$ for $10 \mathrm{~min}$ at $4{ }^{\circ} \mathrm{C}$ the RNA pellet was washed twice with $3 \mathrm{M}$ sodium acetate $\mathrm{pH} 5 \cdot 2$ and twice with $70 \%$ ethanol, and dried under vacuum. The RNA pellet was redissolved in $\mathrm{H}_{2} \mathrm{O}$ and used for RT-PCR following the instructions of the manufacturers ( $3^{\prime}$ RACE system, Gibco BRL). The following primers were used: P3, 5'-CGACTGCAGTGGAACACGTTTCACAGC-3'; an oligo(dT)-adapter primer (AP); and the universal amplification primer (UAP) of the 3' RACE system kit. To facilitate cloning, primer $\mathrm{P} 3$ contains a $P_{s} \mathrm{I}$ restriction site (shown underlined) and primer UAP a $S a l$ site. The RT-PCR products were eluted from agarose gel, restricted with $S_{a} l \mathrm{I}$ and $P_{s t} \mathrm{I}$ and ligated into the $S_{a} l \mathrm{I}$ and Pst I sites of the polylinker region of pBluescript SK- The ligation products were transformed into $E$. coli XL1 Blue. A cDNA clone was obtained and DNA sequences of the genomic PCR and the CDNA clones were determined by standard procedures. Also the $2.1 \mathrm{~kb} \mathrm{BamHI} / P_{s t} \mathrm{I}$ fragment, a part of the genomic clone containing the whole 4-dihydromethyl-TA dehydrogenase gene, was sequenced on both strands.

\section{RESULTS}

\section{Isolation and characterization of the 4-dihydromethyl-TA dehydrogenase}

In order to optimize protein yield, cultures of ( - )-type $M$. macedo were pretreated with TA, which increased the

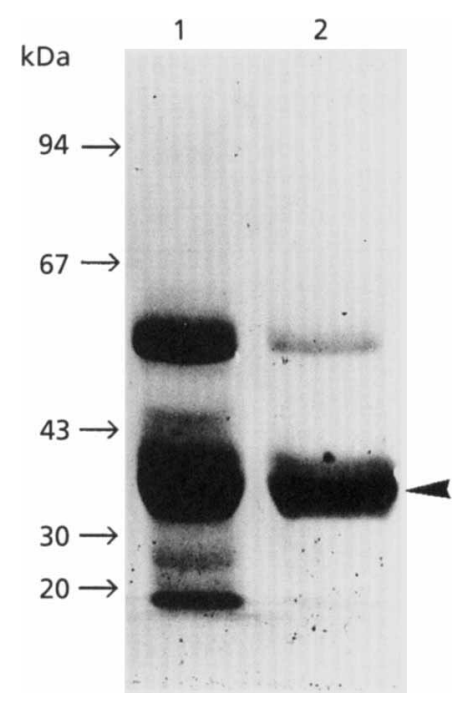

Fig. 1. Separation of purified 4-dihydromethyl-TA dehydrogenase by SDS-PAGE. Lanes 1 and 2, samples of several 4-dihydromethyl-TA dehydrogenase preparations; the arrow marks the band cut out for protein sequencing. Proteins were visualized with Ponceau $S$ staining solution.

enzyme activity up to 15 -fold. This is in accordance with previous results (Werkman, 1976). Induction of enzyme activity was also found with $\beta$-ionone, which stimulates the production of $\beta$-carotene (Eslava et al., 1974). After affinity chromatography the proteins were separated by SDS-PAGE. Three bands, with molecular masses of 33, 36 and $57 \mathrm{kDa}$, could be detected (Fig. 1). Some preparations of activity peaks after affinity chromatography did not contain the $57 \mathrm{kDa}$ protein. The $33 \mathrm{kDa}$ protein was elutcd and renatured according to Hager \& Burgess (1980), and enzyme activity was measured. The renatured fraction retained $87 \%$ of the original activity. Renaturation experiments with the $36 \mathrm{kDa}$ protein were not successful. Therefore, we ascribed the 4dihydromethyl-TA dehydrogenase activity to the $33 \mathrm{kDa}$ band.

\section{Determination of the protein sequence and cloning of the gene for 4-dihydromethyl-TA dehydrogenase}

The proteins from the final electrophoresis purification step were stained with Ponceau solution, cut out and subjected to Edman degradation. Because the $\mathrm{N}$-terminus was blocked, successful sequencing required digestion with the endoprotease Lys-C. Several peptide sequences were determined (Table 1). Protein sequence data were used to design the degenerate primers P1 and P2 (see Methods). These primers were used for PCR, and products could be found at an annealing temperature of $45^{\circ} \mathrm{C}$. A major PCR product with a length of $0.7 \mathrm{~kb}$ was isolated from an agarose gel and cloned in pTZ18R and pBluescript $\mathrm{KS}+/-$ in order to determine the DNA sequence. The PCR clone detected a $4.5 \mathrm{~kb} \mathrm{BamHI} / \mathrm{Sacl}$ fragment in Southern-blot analysis with (-)-type $M$. 
Table 1. Sequences of polypeptides of the 4-dihydromethyl-TA dehydrogenase obtained by digestion with endoprotease Lys-C

The asterisks mark uncertain positions. Numbers indicate codon positions of the amino acid sequence of the ORF.

\begin{tabular}{|ccc|}
\hline No. & Peptide sequence & $\begin{array}{c}\text { Codon } \\
\text { position }\end{array}$ \\
\hline 1 & $\begin{array}{c}\text { MGYRLFDGAEDYG } \\
\text { IETOSIKL A }\end{array}$ & $40-52$ \\
& S TAG P \\
& F V & \\
3 & REDLFIVT & $72-80$ \\
4 & LWNTFHSK & $81-88$ \\
5 & TYTSLLEHASVK & $233-244$ \\
& NQVLLRWALDREFAVIIK & $255-272$ \\
\hline
\end{tabular}

mucedo genomic DNA. A partial gene library was screened, containing restriction fragments with the expected length, and the corresponding genomic clone was isolated. For isolation of a cDNA clone, RNA was isolated from TAinduced ( - )-type $M$. mucedo cultures. A cDNA clone was obtained by reverse transcription of the RNA combined with PCR (RT-PCR).

\section{Sequence analysis of the cloned gene for 4-dihydromethyl-TA dehydrogenase}

DNA sequence data revealed that all the sequenced polypeptides could be localized in the gene (Table 1). Deviations between DNA and protein sequence were found in peptide 1 in codon position 49. This is probably due to contamination of this fragment with other peptides. A second deviation was found in peptide 5 at codon position 271, where the proline predicted by the IDNA sequence was determined as isoleucine in the peptide. In both codon positions no sequence deviations were found between cDNA and genomic DNA. This excludes an RNA-editing mechanism for these peptide sequence changes. No further sequence deviations were found between cDNA clone, genomic sequence and protein sequence. The poly(A) tail was added to nucleotide 1458 of the genomic sequence (Fig. 2). A putative polyadenylation site was found at position 1430.

A short (74 bp) intron disrupts the open reading frame, starting at position 687 of the nucleotide sequence (Fig. 2). The cDNA clone contains no part of the intron sequence, indicating that the intron is spliced correctly. The intron characteristics are very similar to those of other introns of zygomycetes, such as those of the gene for elongation factor $1 \alpha$ of Mucor racemosus (Sundstrom et al., 1987) and A.glauca (Burmester, 1995) and the gene for orotidine-5'-phosphate decarboxylase of $P$. blakesleeanus (Díaz-Mínguez et al., 1990), Mucor circinelloides (Benito et al., 1992) and Rbizopus niveus (Horiuchi et al., 1995). Only introns of small size have been found in zygomycetes, and
GGATCCGCGGGAAAATAGTAAAGAAGTTGGGTGCGT TAGTGCT TACAACTTAAACAAGAA TATCT CTAACT TACACACACACACACATAATATAACGGACAGTT TTTATATCACAAAGTA AGGTAAAGGCATTCAAAAT GTGGGTAGAAAATTCAAACTTTITGATGTGCTGTATTATAA TTAGGTGAATITITITTIITTCATTTAGTGCCACAGTTITGAAGCGGCCATITAAACCCC AGGAAAAAAAAAAAGGCCTATATAAACAAGAGGTTTTGGGTTCTGTTTCTTACTTTTTT TITTCTICTCTTGATTATATTCACACACACATACT CAAATTAAAAATGTCCACTGATTA $M$ S T $D$ Y CCTTACCT TGAACAGAACCGGCGACAAGATGCCCATTCGCGGTTTCGGCTGTTGGAAGAT

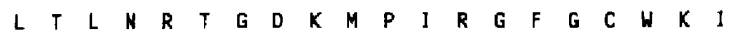
TGACACCAAGgATTGTGAGGAGACCGTCIACCAAGCTATCAAGACTGGTTACCGTCTITT

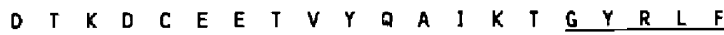
CGATGGT GCCTGTGATTATGGTAACGAAGTCGAGGTTGGTCGTGGTATTAACAAGGCCAT

$\begin{array}{llllllllllllllllllll}D & G & A & C & D & Y & G & N & E & V & E & V & G & R & G & 1 & N & K & A & 1\end{array}$ CAACGAAGGTTTGGICAAGAGAGAAGATCTTITCATCGTCACCAAGCTCTGGAACACCTT

N E G L V V K R E CCACAGCAAGAAGCACGTCCGIGCCTTGTTCGATAGACAATTAAAGGATACCGGTCTTGA

$\begin{array}{llllllllllllllllllll}H & S & K & K & H & V & R & A & L & F & D & R & Q & L & K & D & T & G & L & E\end{array}$ ATACTTTGATCTTTATCTCATTCAITGTAAGTACATTTTAAGACGCGTCATTCGTTTGTT

Y F D L Y Y L I H GGGGGGTTATTAGTATACTAACTCTIACATTCTTAACTAGTCCCCGTTCCCTIGCAATAT $F$ P V P L O Y GTTGACCCTGCTACCGTCTACCCTCCCGGTIGGIATGTCGGTGATGCCAAGTCTCTTCAA V IICGAGCAATCTCCCATCCACGAATGTTGGGCTGAGTTAGAAAAGATTGTCGATGCTGGT

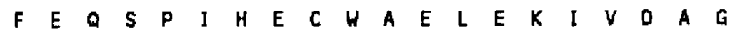
ITGGCTCGTAACATTGGTGITGCTAACTTCAACTGTCAAGCTATCTTGGACTIGCTIACC

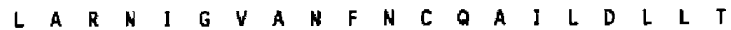
IATGCCAGAAT TAAGCCTGCCGIIIIACAAATCGAACICCATCCTTACTTGCCTCAAGAG Y A A R I I K P CGITTGGTCAAGTGGGTCAAGGAACAAGGTATTCARATTACTGCTTACTCTICIITCGGT 1080 $\begin{array}{llllllllllllllllllllll}R & L & V & K & W & V & K & E & Q & G & \text { I } & Q & \text { I } & \text { T } & \text { A } & \text { Y } & \text { S } & S & F & G & 220\end{array}$ CCTACCTCTTATGTTGACTIGACTGAATCTGGTAAGACTIATACCTCTITGCICGAACAC 1140

$\begin{array}{lllllllllllllllllllll}P & T & S & Y & V & D & L & T & E & S & G & K & I & Y & I & S & L & L & E & H & 240\end{array}$ GCCAGTGTCAAGTCTGTTGCCGATAAGCACAACGICTCCACTGGTCAAGTCTTGCTCCGT 1200 $\begin{array}{lllllllllllllllllllll}A & S & V & K & S & V & A & D & K & H & N & V & S & T & G & Q & V & L & L & R & 260\end{array}$ IGGGCIITGGACCGTGAATTCGCTGT TATCCCCAAGAGTGTTAACGCTGGTAGAATGAAG 1260 $\begin{array}{lllllllllllllllllllll}W & A & L & D & R & E & F & A & V & 1 & P & K & S & V & N & A & G & R & M & K & 280\end{array}$ GCTAACTTGGARATCTTGGATATCAAGC TCGATGCTGAGGATAACAAGACTITGGATTCT 1320 A N N L CTCAAGACCAACCAAAGATICAACGATCCCATGACCTACGGTTTCGGTTTGCCTCTTTTC 1380

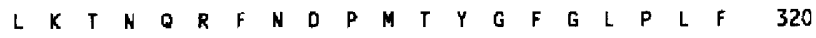
GATTAAGCAATACACACACATACACACACACACACACCCCTIGTAATITAATAAATACCG 1440 D -

CAATITITITITCATCAGTCACTITITITTATtTAACTAATGTtGtTCAATACCGGCT 1500

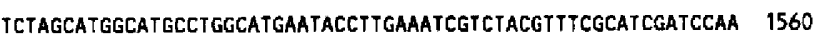
AGCATAGTTTCTGCATAGGTTITGGGTAAGATACGACGCAATTICACTTTATCGTTTCCT 1620 GAAGCCAAGGTGAAATGGAAAACATTGGTAGTTTCACGCGTACCCITTTCAATATTAATG 1680 ACCTCTGCAATGACACGGACTIGTACTGACCGATGTGGGTATCCCICGGATAAAACAATA 1740 CCTGATCTCAAATTCAATAATGTACCCACATGCACTGGCTTTCGAAAAGTGACTTCATCC 1800 ATCGACAACAAGGTAGGTGAGGAAGTCTTCATGAaGAGAGCAGTAITTGCATACGCCAAT 1860 TCATAGGCACGACGCAT CAAG TAACCACCAAAGATAITGTTGTGCAGGTTACGATCTTGA 1920 GGCTGCATTAAAAAATTACTITCAATCTTTGTATCACGCATCCAAACTAGGT TAGAAGGC 1980 AATGGCTGCATTTCATCAGACGATTGAGAGT TCATAAAGGCGTCATCACCTGTACCGTTG 2040 GTGTACTGAGAATACTGCAG

2060

Fig. 2. Nucleotide sequence of the 4-dihydromethyl-TA dehydrogenase. Underlined parts of the nucleotide sequence correspond to the CDNA clone. Sequenced parts of the protein are also underlined. The asterisk marks the position of the poly(A) tail in the CDNA sequence. The CACA boxes are shown in bold.

the $5^{\prime}$ and $3^{\prime}$ motifs match with consensus motifs known for other eukaryotes. The intron presented here distupts codon 34 , for phenylalanine, of the protein sequence. 
Table 2. Percentage identity in pairwise comparison of the protein sequence for the dihydromethyl-TA dehydrogenase with other members of the aldo/keto reductase superfamily

Top half, percentage identity; bottom half, number of identities/number of residue pairs compared (without gaps). Proteins were as follows: 1 , rat $3 \alpha$-hydroxysteroid dehydrogenase (Pawlowski et al., 1991); 2, human aldose reductase (Chung \& LaMendola, 1989); 3, Pichia xylitol reductase (Amore et al., 1991); 4, Muor 4-dihydromerhyl-TA dehydrogenase; 5, Hordeum aldose reductase (Bartels et al., 1991); 6, $S_{\text {accharomyces GCY }}$ protein (Oechsner et al., 1988); 7, L eishmania putative reductase (Samaras \& Spithill, 1989); 8, Pseudomonas morphine dehydrogenase (Willey et al., 1993).

\begin{tabular}{|cccccccccc|}
\hline No. & $\mathbf{1}$ & $\mathbf{2}$ & $\mathbf{3}$ & $\mathbf{4}$ & $\mathbf{5}$ & $\mathbf{6}$ & $\mathbf{7}$ & $\mathbf{8}$ \\
\cline { 1 - 4 } $\mathbf{1}$ & & 45 & 29 & 30 & 27 & 27 & 25 & 22 \\
$\mathbf{2}$ & $133 /$ & & 37 & 35 & 32 & 36 & 35 & 31 \\
& 295 & & & & & & & \\
$\mathbf{3}$ & $87 /$ & $111 /$ & & 47 & 31 & 24 & 29 & 28 \\
& 299 & 299 & & & & & & \\
$\mathbf{4}$ & $90 /$ & $105 /$ & $142 /$ & & 29 & 24 & 25 & 28 \\
& 299 & 299 & 299 & & & & & \\
$\mathbf{5}$ & $81 /$ & $93 /$ & $93 /$ & $86 /$ & & 30 & 27 & 26 \\
& 295 & 291 & 299 & 299 & & & & \\
6 & $80 /$ & $105 /$ & $73 /$ & $71 /$ & $86 /$ & & 31 & 28 \\
& 295 & 291 & 299 & 299 & 283 & & & \\
7 & $75 /$ & $101 /$ & $86 /$ & $76 /$ & $75 /$ & $87 /$ & & 38 \\
& 295 & 291 & 299 & 299 & 276 & 283 & & \\
$\mathbf{8}$ & $64 /$ & $89 /$ & $83 /$ & $84 /$ & $73 /$ & $79 /$ & $102 /$ & \\
& 295 & 291 & 299 & 299 & 276 & 283 & 269 & \\
\hline
\end{tabular}

A sequence motif of CACA repeats flanked the open reading frame. It could be detected at nucleotide positions $323-335$, in the vicinity of the putative translational start codon region, and at positions 1391-1417, immediately after the putative translational stop codon. The last region is also part of the cDNA clone. Whether the $5^{\prime}$ box is also transcribed cannot be answered, because the cDNA clone does not contain the complete $5^{\prime}$ end. A third CACA box is at positions $72-87$ of the promoter region. Additionally, the promoter contains pyrimidine-rich stretches, similar to those found in the promoter of the elongation factor $1 \alpha$ from A. glauca (Burmester, 1995). A putative TATA box starts at position 317 .

Protein sequence comparison with data from the SwissProt database shows similarity to proteins belonging to the aldo/keto-reductase superfamily. Highest similarity is found to the NADPH-dependent xylose teductase of the yeast Pichia stipitis (Amore et al., 1991). The proteins share an identity of $47 \%$ at the amino acid level (Table 2). Fig. 3 shows alignments of some protein examples, all belonging to the aldo/keto-reductase superfamily. There was no significant similarity to dehydrogenases belonging to other superfamilies, such as the short-chain dehydrogenases, or the zinc-containing alcohol dehydrogenases.

The percentages of identical amino acid positions of some

$\begin{array}{lrrr}\text { 1) Rattus } & \text { HDH } & \text { MDSISLRVA } & 9 \\ \text { 2) Homo } & \text { ALR } & \text { ASRLL } & 5 \\ \text { 3) Pichia } & \text { XYR } & \text { MPSIK } & 5 \\ \text { 4) Mucor } & \text { TDH } & \text { MSTDYLT } & 7 \\ \text { 5) Hordeum } & \text { ALR } & \text { MASAKATMGOGEQDHF } & 16 \\ \text { 6) Saccharamyces } & \text { GCY } & \text { MPATLHDSTKILS } & 13 \\ \text { 7) Lefstmania } & \text { PUR } & \text { MAGVOKAMVT } & 10 \\ \text { 8) Pseudomonas } & \text { MDH } & \text { MAGKSP } & 6\end{array}$

1) LN-DGNFIPVLGFGTTYPEKVAKDEVIKATKIALDNGFRHFOSAYLYEVE 58 2) LN-NGAKMPILGLGTW---KSPPGOVTEAVKVALDVGYRHIDCAHVYONE $\mathbf{5 1}$ 3) LN-SGYDMPAVGFGCH---KVDVD TCSEQJYRAIKTGYRL FOGAEDYANE 51 4) LNR TGDKMP [RGFGCW---KIDTKDCEE TVYOAIKTGYRL FDGACDYGNE 54 5) L-KSGHAMPAVGLGTWRAGSDTAHSVRTA - - -TEAGYRHVDTAAEYGVE 62 6) LN-TGAQIPQIGLGTW---OSKENDAYKAVLTALLOGYRHIDTAAIYRNE 59 7) LSN-GVKMPOFGL GVH--QSPAGEVTENAVKWALCAGYRHIDTAAIYKNE 57 B) LNN-GVKCMPALGLGVF - AASAEE - TASAIASAI SSGYRL IOTARSYNNE 52

1) EEVGQA IRSKIEDGTVKRED I FYTSKLLSTFHRPELURTCLEXTLKSTQL 108 2) NEVGVAIQEKLREQWKREEL F IVSKLWCTYHEKGLVKGACOKTLSDLKL 101 3) KLVGAGVKKA IDEG IVKREDL FLTSKL WNWYHHPDNVEKALNRTLSDLQV 101 4) VEVGRG]NKA INEGL VKREDLF [VTKLLWT FHSKKHVRALFDRQLKCTGL 104

5) KEVGKGLKAAMEAG-1DRKDL FVTSKIWC FNLAPERVRPALENTLKDLOL 111

6) DQVGQAIK - - - DSGYPREE I FVTTKLLCTOHHEPEV - ALDQSLKRLGL 103

7) ESVGAGLR - - - ASGVPREDVF I TTKLUNTEQGYESTLAAFEESROKLGV 103

8) AQVGEGIR - - - NS-VDRAEMFYTTKLFNCDYGYERALRAFDESLGRLGL 97 *** $\star * *$

1) DYYDLYI] HFPMALQ -..-PGD IFFPRD - . -EHGKLLFETVDICDTHEA 150 2) DYLDLYLI HWPIGFK ----PGKEFFPLD----ESGNVVPSOTNILDTWAA 143 3) DYVDLFL I HFPVTFK- - FVPLEEKYPPGFYCGKGDNFDYEDVPILETHKA 149 4) EYFDLYL]HFPVPLQ - YVOPATYYPPGWYVGDAKSLQFEQSPI HECWAE 152

5) DYIDLYHJ HWPFRLK - - - - DGAHMPPE - - - -AGEVLEFDNEGV - - - WKE 149 6) DYVDLYLMHWPARLDPAYIKNED ILSVPIKKDGSRAVDITNWNFIKTWEL 153

7) DYIDLYLI HWPR -

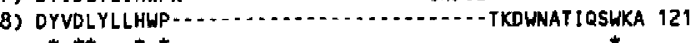
*****

1) MEKCKDAGLAKSIGVSNFNCROLERILNKPGLXYKPVCNQVECHLYLNOS 200

2) MEELVDEGLVKAIG] SNFNHLOVEMI LNKPGLKYKPAVWQIECHPYLTOE 193

3) LEKLVKAGKIRSI GVSNFPGALLLDLLRGATIK--PSVLQVEHHPYLQQP 197

4) LEKIVDAGLARNI GVANFNCOAILDLITYARIK - PAVLQIEL HPYLPQE 200

5) MENLVKDGLVKOIGVCNYTVTKLLRR LRSAKIP - - PAVCOMEMHPGUKND 197

6) MOELPKTGKTKAVGVSNFSINNLKDLLASOGNKLTPAANQVEI HPLLPOD 203

7) FEQLYKEKKVRAIGVSNFHI HHLEDVLAMCTVT - PMVNQVELHPLNNOA 181

8) AEKILGDGRARA I GVCNFLEDOLDEL IAASOWV - PAVNO!ELHPYFAOK 169 *** $*$

1) KMLDYCKSKDIILVSYCTLGSSRDKTHVDQKS - - - PVLLDDPVLCALAK 246

2) KLIQYCDSKGIWTAYSPLGSP-DRPWAKPED -...PSLLEDPR]KA [AA 238

3) RLIEFAQSRGIAVTAYSSFGPQSFVELNOGRALNT - SPLFENET IKALAA 246

4) RLVKWVKEOGIQ1TAYSSFGPTSYVDLTES-GKTY-TSLLEHASVKSVAD 248

5) KJFEACKKHGIHVTAYSPLGSSE -...............

6) ELINFCKSKGIVVEAYSPLGSTD - ................

7) DLRAFCDAKQIKVEAWSPLG -.....................

8) PLLAKNRALGIVTEAWSPIGCHQ - RHQDGDNHGGRKHPLTOPVITTLAE 217

1) KYKQTPALVALRYOLORGWPLIRSFNAKR IKELTOVFEFOLASEDMKAL 296

2) KHNXTTAQVLIRFPMORNLWIPKSVTPERIAENFKVFDFELSSODMTTL 288

3) KHGKSPAQVLLRWSSRRGIAI IPKSNTVPRLLENKDVNSFDLDEODFAO I 296

4) KHNVSTGQVLLRWALDREFAVIPKSVNAGRMKANLEILDIKLDAEDNKTL 298

5) KLNKT PGQVL IKWALQRGISVIPKSSKDER IKENI QVFGWE:PEEDFKVL 284

6) KNHVOPGHVVI SHHVORGYVIPKSVNPDR IKTNRKI FT--LSTEDFEAI 288

7) KYNKTAAQVILRWN I OKNL I IPKSVHRER IEENAD I FDFELGAEDVMSI 266

8) AHGRSAAQVILRWHFQNDVVAIPKSVNPER IAKNIDVFOFALSDAEMAQL 267

1) DGLNRN FRYNAAKYFDDHPNHPFTDE

2) LSYMRNURVCALLSCTSHKDYPFHEEF

2) LSYMRWURVCALLSCTSHKDYPFHE

4) DSLKTKQR FNDPHTYGFGLPLFD

5) CSIKDEKRVLTGEELFVNKTHGPYRSAADVHDHEN

6) NNISKEKGEKRVVHPNUSPFEVFK

7) DALNTWSRYGPDPDEAOF

8) DELDTGVRIGPDPRDVDTSSFAEFV

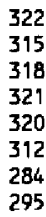

Fig. 3. Alignment of protein sequences of the 4-dihydromethylTA dehydrogenase with other members of the aldo/keto reductase superfamily. Asterisks mark identical positions. Abbreviations: $\mathrm{HDH}, 3 \alpha$-hydroxysteroid dehydrogenase; ALR, aldose reductase; $X Y R$, xylitol reductase; TDH, 4-dihydromethylTA dehydrogenase; GCY, GCY protein; PUR, putative reductase; $\mathrm{MDH}$, morphine dehydrogenase.

members of the aldo/keto-reductase superfamily are shown in Table 2. Values were obtained by comparison of the same fragment length of all proteins, which corre- 


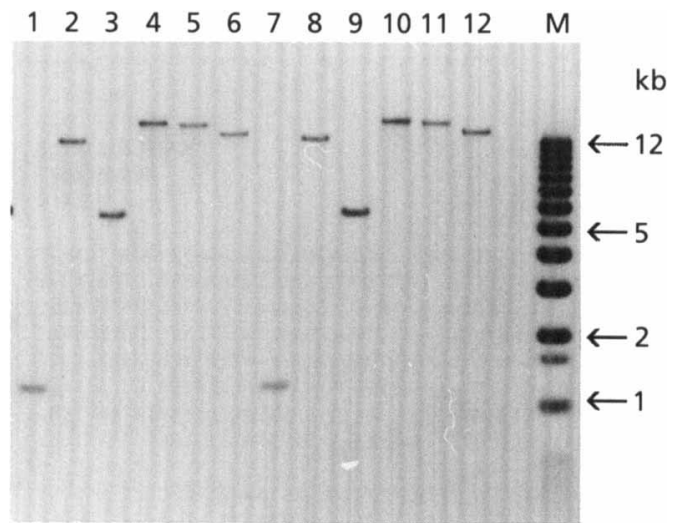

Fig. 4. Southern-blot analysis of genomic DNA of $M$. mucedo with the cloned PCR fragment of the 4-dihydromethyl-TA dehydrogenase. Genomic DNAs of $M$. mucedo strains CBS 144.24(+) (lanes 1-6) and CBS 106.16(-) (lanes 7-12) were restricted with EcoRI, Pstl, BamHI, HindIII, Pvull and Sacl in that order. The $1 \mathrm{~kb}$ ladder (Gibco BRL) was used as size marker (M).

sponded to amino acids 8-306 of the 4-dihydromethylTA dehydrogenase.

\section{Hybridization analysis and PCR assay with genomic DNA of other zygomycetes}

Genomic DNAs of $M$. mucedo $(+)$ and $(-)$ strains were digested with EroRI, PstI, Bam HI, HindIII, PvuII and SacI. The corresponding blots were hybridized with a labelled probe of the cloned PCR fragment, and only one band was seen in all lanes (Fig. 4). Therefore we conciude that only a single copy of this gene is present in the genome of both mating types. No polymorphism could be detected between the two mating types, which indicates that the adjacent regions are conserved.
PCR primed by degenerated primers with genomic DNA templates of other zygomycetes, A. glanca, P. parasitica and $B$. trispora, gave rise to a multiple band pattern on agarose gels (Fig. 5a). Hybridization of the corresponding blot with the labclled PCR fragment of $M$. mucedo showed that only one band in all lanes cross-hybridized. This band had a similar size to the PCR product from $M$. mucedo DNA (Fig. 5b). No hybridization signals were obtained for either mating type of $P$. blakesleeanus.

\section{DISCUSSION}

Little is known about the genetic basis of sexual differentiation in zygomycetes. This report presents the analysis of one gene of the sexual pheromone pathway and sequence comparison data show that the 4dihydromethyl-TA dehydrogenase of $M$. mucedo belongs to the ardo/keto reductase superfamily. Most enzymes belonging to this superfamily prefer $\mathrm{NADP} / \mathrm{H}$ as cofactor.

Comparison of a bacterial morphine dehydrogenase (Bruce et al., 1994) with other members of the aldo/keto reductase superfamily distinguishes three subgroups in this superfamily. Subgroup I contains the mammalian aldose reductases and human aldehyde reductase; subgroup II contains other mammalian oxidoreductases with a wide variety of substrates. Members of subgroup III share lower similarities to each other; here we find bacterial enzymes, e.g. the morphine dehydrogenase of Pseudomonas putida (Willey et al., 1993) and the 2,5-diketoD-gluconate reductase of Corynebacterium sp. (Grindley ot al., 1988), and eukaryotic enzymes such as a putative reductase of Leishmania major (Samaras \& Spithill, 1989) and the GCY protein of Saccharomyces cerevisiae (Oechsner et al., 1988). Some members of the superfamily cannot be placed in the three subgroups and probably represent additional subgroups. Examples were the xylitol reductase
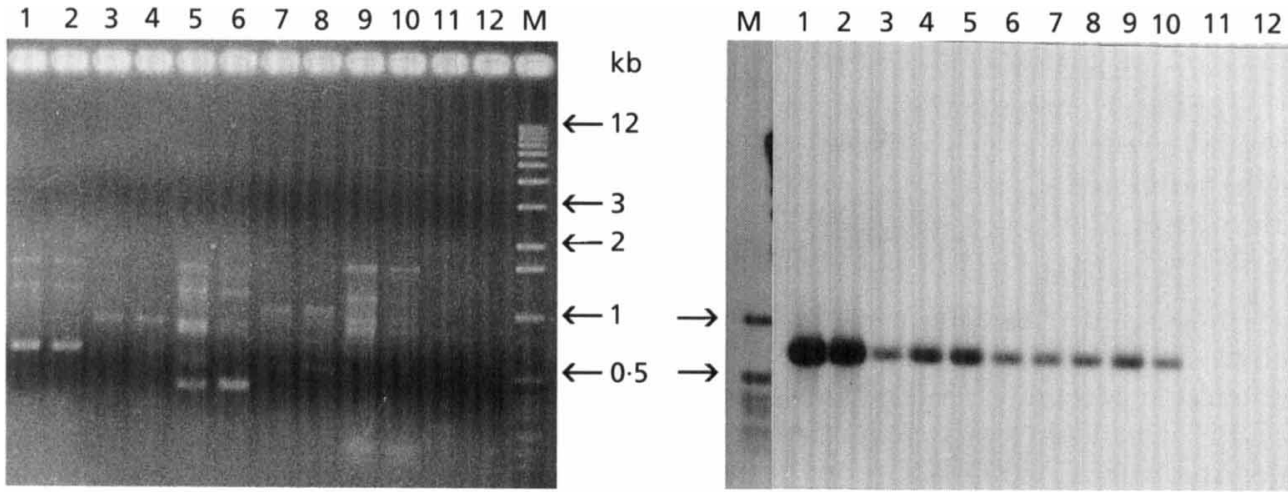

Fig. 5. PCR with genomic DNAs of other zygomycetes. PCR products were separated on a $1 \cdot 2 \%$ agarose gel and the gel was blotted. The blot was hybridized with a radioactively labelled probe of the cloned PCR fragment of $M$. mucedo, containing parts of the 4-dihydromethyl-TA dehydrogenase gene. DNAs of the following strains were used: $M$. mucedo CBS 109.16 (lane 1) and CBS 144.24 (lane 2); B. trispora CBS 131.59 (lane 3) and CBS 130.59 (lane 4); P. parasitica ATCC 11077 (lane 5), CBS 412.66 (lane 6), CBS 208.28 (lane 7) and CBS 207.28 (lane 8); A. glauca CBS 101.48 (lane 9) and CBS 100.48 (lane 10); P. blakesleeanus (-) mating type (lane 11) and (+) mating type (lane 12). The $1 \mathrm{~kb}$ ladder (Gibco $\mathrm{BRL}$ ) was used as size marker (M). 
of Pichia stipitis (Amore et al., 1991) and the aldose reductase of Hordeum vulgare (Bartels $t$ t al., 1991). The degree of identical amino acid positions, summarized in Table 2 , shows that the xylitol reductase of $P$. stipitis has the highest similarity to the 4-dihydromethyl-TA dehydrogenase of $M$. mucedo. Comparison of the three fungal sequences shows that the xylitol reductase and 4dihydromethyl-TA dehydrogenase show a higher similarity to sequences of subgroup I and II than to the GCY protein of yeast. One might speculate that distinction between the two types of genes arose at a very early point of evolution, similarly perhaps as the homologies found between the elongation factor I and II genes, which are discussed as a result of duplication of the universal ancestor (Hasegawa et al., 1992).

Analysis of the structural components of the human aldose reductase (Wilson $t$ t al., 1992) gives interesting clues for the deduced protein sequence of the 4 dihydtomethyl-TA dehydrogenase. In human aldose reductase the substrate-binding site is located in a large deep elliptical pocket at the $\mathrm{COOH}$-terminus with a bound NADPH in an extended conformation. The hydrophobic nature of the active site favours aromatic and apolar substrates over highly polar monosaccharides. Thus compounds such as isocorticosteroids are the best substrates for aldose reductase (Wilson et al, , 1992). In the aldo/keto reductase superfamily substrates are often hydrophobic substances like steroids or in our case 4 dihydromethyl-TA, which is a detivative of $\beta$-carotene.

In aldose reductase two possible sites, a tyrosine at position 48 or a histidine at position 110 , might act as hydrogen donors in transferring hydrogen. Both regions are highly conserved in all proteins of the superfamily. The 4-dihydromethyl-TA dehydrogenase contains both hydrogen donor/acceptor sites found by similarity at positions 51 and 113 of the amino acid sequence (Fig. 3).

The promoter region of the gene for 4-dihydromethyl$T A$ dehydrogenase contains sequence elements, the CACA boxes, which were also found in a cAMP-regulated stage-specific gene of Dictyostelium discoideum (Haberstroh \& Firtel, 1990). Promoter deletion experiments showed that deletion of these boxes resulted in a loss of cAMP and developmentally induced expression (Haberstroh \& Firtel, 1990). Similar promoter studies of the gene for 4dihydromethyl-TA dehydrogenase should shed light on the role of these sequence motifs in Mucor.

PCR experiments with DNAs of other zygomycetes show that it is possible to identify genes homologous to the $M$. mucedo 4-dihydromethyl-TA dehydrogenase gene from $P$. parasitica and $A$. glauca. Transformation with gene teplacement vectors will allow the knockout of these genes. Thus, we may be able to reveal molecular links between parasitic and sexual development.

\section{ACKNOWLEDGEMENTS}

We thank Professor H. van den Ende for his advice and help in the initial phase of the project. This work was supported by grants from Deutsche Forschungsgemeinschaft and Fonds der Chemischen Industrie.

\section{REFERENCES}

Amore, R., Kötter, P., Küster, C., Ciriacy, M. \& Hollenberg، C. P. (1991). Cloning and expression in Sacharomyes cerevisiae of the $\mathrm{N} A D(\mathrm{P}) \mathrm{H}$-dependent xylose reductase-encoding gene (XYL1) from the xylose-assimilating yeast Pichia stipitis. Gene 109, 89-97.

Bartels, D., Engelhardt, K., Roncarati, R., Schneider, K., Rotter, M. \& Salamini, F. (1991). An $A B A$ and (GA modulated gene expressed in the barley embryo encodes an aldolase reductase related protein. EMBO J 10, 1037-1043.

Benito, E. P., Dlaz-Mínguez, J. M., Iturriaga, E. A., Campuzano, V. \& Eslava, A. P. (1992). Cloning and sequence analysis of the $M u c o r$ circinelloides fyrG gene encoding orotidine-5'monophosphate decarboxylase: use of pyr $G$ for homologous transformation. Gene $116,59-67$.

Blakeslee, A. F. \& Cartledge, J. L. (1927). Sexual dimorphism in Mucorales. II. Interspecific reactions. Bot Gå 84, 51-57.

Braun, H. P., Kruft, V. \& Schmitz, U. K. (1994). Molecular identification of the ten subunits of cytochrome- $c$ reductase from potato mitochondria. Planta 193, 99-106.

Bruce, N. C., Willey, D. L., Coulson, A. F. W. \& Jeffery, J. (1994). Bacterial morphine dehydrogenase further defines a distinct superfamily of oxidoreductases with diverse functional activities. Bischem J 299, 805-811.

Bullock, W. O., Fernandez, J. M. \& Short, J. M. (1987). Xl1-blue: a high efficiency plasmid transforming rec.A Escherichia coli strain with $\beta$-galactosidase selection. Biotechniques 5, 376-379.

Bu'Lock, J. D., Jones, B. E. \& Winskill, N. (1976). The apocarotenoid system of sex hormones and prohormones in mucorales. Pure. Appt Cbem 47, 191-202.

Burgeff, H. (1924). Untersuchungen über Sexualität und Parasitismus bei Mucorineen. Bot Abs 4, 5-135

Burmester, A. (1995). Analysis of the gene for the elongation factor $1 \alpha$ from the zygomycete Absidia glawi. Use of the promoter region for constructions of transformation vectors. Microbiol Res 150, 63-70.

Burmester, A. \& Czempinski, K. (1994). Sequence comparison of a segment of the gene for 3-hydroxy-3-methylglutaryl-coenzyme A reductasc in zygomycetes. Eur J Biochem 220, 403-408.

Burmester, A. \& Wöstemeyer, J. (1986). Cioned mitochondrial DNA from the zygomycete Absidia glauca promotes autonomous replication in Sacbaromyces cerevisiae. Curr Genet 10, 435-441.

Chung, S. \& LaMendola, J. (1989). Cloning and sequence determination of human placental aldose reductase gene. $J$ Biol Chem 264, 14775-14777.

Dlaz-Mínguez, J. M., Iturriaga, E. A., Benito, E. P., Corrochano, L. M. \& Eslava, A. P. (1990). Isolation and molecular analysis of the orotidine-5'-phosphate decarboxylase gene (pyrG) of Pbycomyces blakesteeanus. Mol Gen Genet 224, 269-278.

van den Ende, H. (1968). Relarionship between sexuality and carotene synthesis in Blakeslea trispora. J Bacterial 96, 1298-1303.

van den Ende, H. \& Stegwee, D. (1971). Physiology of sex in Mucorales. Bot Rer' 37, 22-36.

Eslava, A. P., Alvarez, M. I. \& Cerda-Olmedo، E. (1974). Regulation of carotene biosynthesis in Pyromyces by vitamin $A$ and $\beta$-ionone. Eur I Biochem 48, 617-623.

Gooday, G. W. (1994). I lormones in mycelial fungi. In The Myota, vol. I, pp. 401-411. Edited by J. G. H. Wessels \& F. Meinhatdt. Berlin: Springer-Verlag. 
Grindley, J. F., Payton, M. A., van de Pol, H. \& Hardy, K. G. (1988). Conversion of glucose to 2-keto-L-gulonate, an intermediate in Lascorbate synthesis, by a recombinant strain of Erwinia citreus. Appl Environ Microbiol 54, 1770-1775.

Haberstroh, L. \& Firtel, R. A. (1990). A spatial gradient of expression of a cAMP-regulated prespore cell-type-specific gene in Dictyostelium. Genes Dev 4, 596-612.

Hager, D. A. \& Burgess, R. R. (1980). Elution of proteins from sodium dodecyl sulfate-polyacrylamide gels, removal of sodium dodecyl sulfate, and renaturation of enzymatic activity: results with Sigma sub-unit of Escherichia coli RNA polymerase, wheat germ DNA topoisomerase, and other enzymes. Anal Biochem 109, 76-86.

Hasegawa, M., Hashimoto, T. \& Adachi, T. (1992). Origin and evolution of cukaryotes as inferred from ptotein sequence data. In The Origin and Evolution of the Cell, pp. 107-130. Edited by H. Hartman \& K. Matsuno. Singapore: World Scientific.

Horiuchi, H., Takaya, N., Yanai, K., Nakamura, M., Ohta, A. \& Takagi, M. (1995). Cloning of the Rbizopus niveus pyr4 gene and its use for the transformation of Rbizopus delemar. Curr Genet 27, $472-478$.

Kellner, M., Burmester, A., Wöstemeyer, A. \& Wöstemeyer, J. (1993). Transfer of genetic information from the mycoparasite Parasitella parasitica to its host Absidia glanca. Curr Genet 23, $334-337$.

Laemmli, U. K. (1970). Cleavage of structural proteins during the assembly of the head of bacteriophage T4. Nature 227, 680-685.

Nachlas, M. M., Margulies, S. I., Goldberg, J. D. \& Seligman, A. M. (1960). The determination of lactic dehydrogenase with a tetrazolium salt. Anal Biochem 1, 317-326.

Nieuwenhuis, M. \& van den Ende, H. (1975). Sex specificity of hormone synthesis in Mucor mucedo. Arch Microbiol 102, 167-169.

Oechsner, U., Magdolen, V. \& Bandlow, W. (1988). A nuclear yeast gene $(G C Y)$ encodes a polypeptide with high homology to a vertebrate eye lens protein. FEBS Lett 238, 123-128.

Pawlowski, J. E., Huizinga, M. \& Penning, T. M. (1991). Cloning and sequencing of the cDNA for tat liver $3 \alpha$-hydroxysteroid/ dihydrodiol dehydrogenase. J Biol Chem 266, 8820-8825.

Samaras, N. \& Spithill, T. W. (1989). The developmentally regulated P100/11E gene of Leishmania major shows homology to a superfamily of reductase genes. J Biol Chem 264, 4251-4254.

Southern, E. M. (1975). Detection of specific sequences among DNA fragments separated by gel electrophoresis. J Mol Biol 98, 503-517.

Stoschek, C. M. (1990). Quantitation of a protein. Metbods Enzymol 182, 50-67.

Sundstrom, P., Lira, L. M., Choi, D., Linz, J. E. \& Sypherd, P. S.

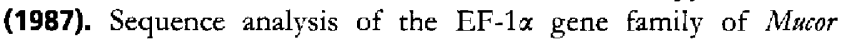
racemosus. Nucleic Acids Res 15, 9997-10006.

Vetter, M., Wostemeyer, J. \& Burmester, A. (1994). Characterization of specific cDNA clones of the zygomycetes Parasitella parasitica, derived from mRNAs which are regulated by the pheromone trisporic acid. Microbiol Res 149, 17-22.

Werkman, B. A. (1976). Localization and partial characterization of a sex-specific enzyme in homothallic and heterothallic mucorales. Arcb Microbiol 109, 209-213.

Werkman, T. A. \& van den Ende, H. (1973). Trisporic acid synthesis in Blakeslea trispora. Interaction between plus and minus mating types. Arch Microbiol 90, 365-374.

Willey, D. L., Caswell, D. A., Lowe, C. R. \& Bruce, N. C. (1993). Nucleotide sequence and over-expression of morphine dehydrogenase, a plasmid-encoded gene from Pseudomonas putida M10. Biocbem J 290, 539-544.

Wilson, D. K., Bohren, K. M., Gabbay, K. H. \& Quiocho, F. A. (1992). An unlikely sugar substrate of the human aldose reductase holoenzyme implicated in diabetic complications. Science 257, 81-84.

Wostemeyer, J. (1985). Strain-dependent variation in ribosomal DNA arrangement in Absidia glaua. Eur J Biocbem 146, 443-448.

Received 22 January 1996; revised 26 April 1996; accepted 9 May 1996. 